\begin{tabular}{llrr}
\hline \hline Volume: & 3 & E-ISSN: & $2655-1942$ \\
Number: & 1 & Terbitan: & Juni 2020 \\
Page : & $121-141$ & & \\
\hline
\end{tabular}

\title{
Implementasi Putusan Mahkamah Konstitusi Nomor 69/PUU-XIII/2015 terhadap Hukum Perkawinan di Indonesia
}

\author{
Herni Widanarti \\ Fakultas Hukum Universitas Diponegoro \\ Email : herniwidanarti13@gmail.com
}

\begin{abstract}
Abstrak
Perjanjian kawin adalah suatu perjanjian yang dibuat atas permintaan dari sepasang calon suami istri, dimana mereka berdua telah setuju dan sepakat untuk membuat pemisahan harta mereka masingmasing. Menurut KUH Perdata dan Undang-Undang Perkawinan, pada prinsipnya perjanjian kawin tidak dapat dilakukan setelah perkawinan berlangsung, namun pada tanggal 27 Oktober 2016 keluarlah "Putusan Mahkamah Konstitusi No. 69/PUU-XIII/2015" yang pada intinya perjanjian kawin dapat dilakukan setelah perkawinan dilangsungkan. Tujuan penelitian ini adalah untuk mengetahui pertimbangan Hakim dalam "Putusan Mahkamah Konstitusi Nomor 69/PUU-XIII/2015" serta menganalisa implementasi putusan tersebut terhadap hukum perkawinan di Indonesia. Penelitian ini menggunakan metode penelitian yuridis empiris yang menggunakan penelitian lapangan dan pendekatan Undang-Undang. Hasil penelitian menunjukkan bahwa lahirnya "Putusan Mahkamah Konstitusi Nomor 69/PUU-XIII/2015" yang membawa perspektif baru tentang kesepakatan perkawinan di mana perjanjian kawin dapat dilakukan selama dalam ikatan perkawinan berlangsung atau setelah perkawinan sesuai dengan kesepakatan kedua belah pihak dengan tidak merugikan pihak ketiga.
\end{abstract}

\section{Kata Kunci : Perkawinan, Perjanjian Perkawinan, Putusan Mahkamah Konstitusi}

\begin{abstract}
Marriage agreement is an agreement made at the request of a pair of prospective husband and wife, where both of them have agreed and agreed to make the separation of their respective property. According to the Civil Code and the Marriage Law, in principle the marriage agreement cannot be carried out after the marriage takes place, but on October 27, 2016 the Constitutional Court ruling came out. 69 / PUU-XIII / 2015 which in essence the marriage agreement can be carried out after marriage. The purpose of this study was to determine the considerations of Judges in the decision of the "Constitutional Court Number 69 / PUU-XIII / 2015" and to analyze the implementation of these decisions on marriage in Indonesia. This study uses an empirical juridical research method that uses field research and a legal approach. The results showed that the birth of the "Constitutional Court Decision Number 69 / PUU-XIII / 2015" which brought a new perspective on marital agreements in which the marriage agreement can be carried out as long as the marriage is underway or after marriage in accordance with the agreement between the two parties by the marriage registrar or the notary and insofar as the third party is not harmed, and the decision is final and has been published in the State Gazette of the Republic of Indonesia so that it applies to all citizens of Indonesia.
\end{abstract}

Keyword : Marriage, Marriage Agreement, Constitutional Court Ruling 


\begin{tabular}{llrr}
\hline \hline Volume: & 3 & E-ISSN: & $2655-1942$ \\
Number: & 1 & Terbitan: & Juni 2020 \\
Page : & $121-141$ & & \\
\hline
\end{tabular}

\section{A. Latar Belakang Masalah}

Perkawinan adalah ikatan lahir batin antara seorang pria dan seorang wanita sebagai suami istri dengan tujuan membentuk keluarga (rumah tangga) yang bahagia dan kekal berdasarkan Ketuhanan Yang Maha Esa”. Selanjutnya "Pasal 2 Ayat (1)" Perkawinan adalah sah, apabila dilakukan menurut hukum masing-masing agamanya dan kepercayaannya itu, dan Ayat (2) “Tiap-tiap perkawinan dicacat menurut peraturan perundang-undangan yang berlaku”.

Dengan adanya ikatan perkawinan antara laki-laki dan perempuan, maka demi hukum terjadi percampuran harta di antara keduanya. ${ }^{1}$ Percampuran harta ini menyebabkan munculnya harta bersama, yaitu keseluruhan harta yang diperoleh selama masa perkawinan. Namun demikian, ada perkecualian terhadap percampuran harta ini, yaitu terhadap harta yang diperoleh sebelum perkawinan, harta yang diperoleh berdasarkan pemberian dan harta yang diperoleh berdasarkan pewarisan Meskipun percampuran harta terjadi demi hukum, tak berarti keadaan ini tidak bisa dihindari. Hukum positif memberikan jalan keluar, yaitu dengan membuat perjanjian perkawinan yang secara tegas memisahkan harta suami dan istri dalam perkawinan.

Dengan perjanjian semacam ini, maka ada pemisahan harta antara suami dan istri. Dengan mengadakan perjanjian perkawinan, kedua calon suami istri adalah berhak menyiapkan beberapa penyimpangan dari peraturan Undang-Undang sekitar persatuan harta kekayaan, asal perjanjian itu tidak menyalahi tata susila yang baik atau tata tertib umum dan asal diindahkan pula segala ketentuan. Yang intinya perjanjian kawin adalah perjanjian mengenai harta benda suami istri selama perkawinan mereka, yang menyimpang dari azas atau pola yang ditetapkan oleh Undang-Undang. Demikian pula dengan hutang-hutang dari masingmasing pihak tersebut akan tetap menjadi tanggungjawab dari pihak yang memiliki hutang tersebut.

Selanjutnya dalam "Pasal 147 juncto 149 KUH Perdata" dinyatakan bahwa perjanjian kawin tersebut harus dibuat dengan akta Notaris sebelum dilangsungkannya perkawinan, perjanjian mana mulai berlaku sejak saat perkawinan dilangsungkan dan tidak boleh ditarik kembali atau diubah dengan bagaimanapun selama berlangsungnya perkawinan.

\footnotetext{
${ }^{1}$ Undang-Undang tentang Perkawinan, UU No. 1 Tahun 1974 (LN No. 1 Tahun 1974, TLN No. 3019) Pasal 35 ayat (1)
} 


\begin{tabular}{llrr}
\hline \hline Volume: & 3 & E-ISSN: & $2655-1942$ \\
Number: & 1 & Terbitan: & Juni 2020 \\
Page : & $121-141$ & & \\
\hline
\end{tabular}

Diatur dalam “Undang-Undang Nomor 1 Tahun 1974 tentang Perkawinan Pasal 29”, yang menentukan bahwa:

1. "Pada waktu atau sebelum perkawinan dilangsungkan, kedua pihak atas persetujuan bersama dapat mengadakan perjanjian tertulis yang disahkan oleh pegawai pencatat perkawinan, setelah mana isinya berlaku juga terhadap pihak ketiga yang tersangkut”.

2. "Perjanjian tersebut tidak dapat disahkan bilamana melanggar batas-batas hukum, agama dan kesusilaan".

3. "Perjanjian tersebut berlaku sejak perkawinan dilangsungkan".

4. "Selama perkawinan berlangsung, perjanjian tersebut tidak dapat diubah kecuali bila dari kedua belah pihak ada persetujuan untuk merubah dan perubahan tidak merugikan pihak ketiga".

Dari ketentuan yang terdapat dalam "Pasal 29 Undang-Undang Perkawinan" tersebut dengan jelas telah diatur bahwa perjanjian kawin tersebut harus dilaksanakan pada waktu atau sebelum perkawinan dilangsungkan, hal serupa juga diatur dalam "Pasal 147 KUH Perdata" yang menyebutkan bahwa perjanjian kawin haruslan dibuat dengan akta Notaris dan harus dibuat sebelum perkawinan dilangsungkan. Berdasarkan peraturan tersebut, KUH Perdata dan Undang-Undang Perkawinan tidak memperbolehkan membuat perjanjian kawin setelah perkawinan dilangsungkan. Kondisi hukum ini berlaku secara tanpa kecuali bagi setiap warga negara Indonesia ("WNI"), termasuk WNI yang kawin dengan warga negara asing ("WNA"),5 maupun WNI yang melangsungkan perkawinan di luar Indonesia.

Permasalahannya kemudian adalah, percampuran harta yang terjadi antara WNI dan WNA menyebabkan gugurnya hak dari WNI yang bersangkutan untuk memiliki tanah dengan titel hak milik ("HM”) hak guna bangunan (“HGB”) maupun Hak Guna Usaha ("HGU”). Permasalahan inilah yang kemudian diujikan di hadapan Mahkamah Konstitusi Republik Indonesia ("MKRI") oleh Ny. Ike Farida. Ketentuan yang dimohonkan untuk diuji adalah ketentuan-ketentuan dalam "Undang-Undang Republik Indonesia Nomor 5 Tahun 1960 tentang Peraturan Dasar Pokok-Pokok Agraria" ("UUPA") dan Undang-Undang Republik Indonesia Nomor 1 Tahun 1974 tentang Perkawinan (“UU Perkawinan”).

Permohonan yang diajukan pada pokoknya bertujuan untuk merincikan status hukum dari WNI sebagai pihak yang berhak memegang tanah dengan titel HM dan HGB, mengubah ketentuan mengenai masa pembuatan perjanjian perkawinan dan perubahannya, serta 


\begin{tabular}{llrr}
\hline \hline Volume: & 3 & E-ISSN: & $2655-1942$ \\
Number: & 1 & Terbitan: & Juni 2020 \\
Page : & $121-141$ & & \\
\hline
\end{tabular}

memberikan batasan terhadap percampuran harta (dengan mengecualikan HM dan HGB ketika perkawinan terjadi antara WNI dan WNA). ${ }^{2}$ Pada tanggal 27 Oktober 2016, Mahkamah Konstitusi mengabulkan sebagian permohonan perkara "Nomor 69/PUUXIII/2015" yang diajukan oleh saudari Ike Farida selaku pemohon. Isi pokok permohonannya adalah terkait dengan uji materi beberapa ketentuan dalam "Undang-undang Nomor 5 Tahun 1960 tentang Peraturan Dasar Pokok-Pokok Agraria dan Undang-Undang Nomor 1 Tahun 1974 Tentang Perkawinan (UU No.1/1974)”.

Pemohon mengajukan uji materi atas "Pasal 21 ayat (1) dan ayat (3), serta Pasal 36 ayat (1) UUPA dan Pasal 29 ayat (1), ayat (3), ayat (4) dan Pasal 35 ayat (1) UU 1/1974. Dengan di keluarkannya putusan Mahkamah Konstitusi No. 69/PUU-XII/2015” yang tertuang dalam amar putusan tersebut akan menimbulkan akibat hukum bagi yg berperkara dan juga seluruh masyarakat Indonesia karena putusan tersebut bersifat final dan berlaku bagi seluruh masyarakat Indonesia. Dengan demikian putusan tersebut perlu ditegakkan secara aktif melalui legislasi dan ajudikasi. Berdasarkan uraian tersebut, penulis tertarik untuk menganalisa akibat hukum yang ditimbulkan atas putusan Mahkamah Konstitusi serta menganalisa Implementasi putusan Mahkamah Konstitusi terhadap hukum perkawinan di Indonesia.

\section{B. Metode Penelitian}

Penelitian ini menggunakan metode penelitian yuridis empiris yang menggunakan penelitian lapangan dan pendekatan Undang-Undangan ${ }^{3}$. Data hukum yang digunakan dalam penelitian ini adalah data hukum primer yaitu data hukum yang diperoleh dari objek penelitian melalui proses wawancara, dan data hukum sekunder yang berupa bahan hukum primer yaitu peraturan perundang-undangan yang terkait ${ }^{4}$ dengan hukum perkawinan di Indonesia, serta bahan hukum sekunder berupa literatur terkait permasalahan dalam penelitian. Data hukum tersebut dikumpulkan melalui wawancara dan studi kepustakaan,

\footnotetext{
${ }^{2}$ Ketentuan Pasal 56 ayat (1) UU Perkawinan menyatakan bahwa perkawinan yang dilakukan oleh warga negara Indonesia di luar Indonesia tidak boleh melanggar ketentuan di dalam UU Perkawinan. Lihat, Indonesia (1), Undang-Undang tentang Perkawinan, Pasal 56 ayat (1)

3 Kornelius Benuf and Muhamad Azhar, 'Metodologi Penelitian Hukum Sebagai Instrumen Mengurai Permasalahan Hukum Kontemporer', Gema Keadilan, 7.1 (2020), Hlm. 25.

${ }^{4}$ Soemitro, Ronny Hanitijo. "Metodologi penelitian hukum dan jurimetri." Ghalia Indonesia, Jakarta 167 (1990).
} 


\begin{tabular}{llrr}
\hline \hline Volume: & 3 & E-ISSN: & $2655-1942$ \\
Number: & 1 & Terbitan: & Juni 2020 \\
Page : & $121-141$ & & \\
\hline
\end{tabular}

kemudian setelah terkumpulkan, dianalisis secara deskriptif analitis, yaitu menggambarkan objek penelitian, dan pada akhirnya menjawab permasalahan dalam penelitian ini.

\section{Hasil Penelitian dan Pembahasan}

\section{Pertimbangan Hakim dalam "Putusan Mahkamah Konstitusi RI No. 69/PUU- XIII/2015"}

Dalam konteks ketatanegaraan Mahkamah Konstitusi menurut Jimly Asshidiqie dikonstruksikan sebagai pengawal konstitusi yang berfungsi menegakkan keadilan konstitusional di tengah kehiduan masyarakat, sehingga Mahkamah Konstitusi juga berfungsi sebagai pengawal demokrasi (the guardian of democracy), pelindung hak konstitusional warga Negara (the protector of citizen's constitutional rights), serta pelindung hak asasi manusia (the protector of human rights). ${ }^{5}$

Sebagai sebuah peradilan konstitusi, Mahkamah Konstitusi memiliki 4 (empat) buah kewenangan dan 1 (satu) kewajiban sebagaimana diatur dalam "Pasal 24 C Ayat (1) dan (2)", yaitu; ${ }^{6}$

a. "Kewenangan mengadili pada tingkat pertama dan terakhir yang putusannya bersifat final untuk menguji undang-undang terhadap Undang-Undang Dasar”.

b. "Memutus sengketa kewenangan lembaga Negara yang kewenangannya diberikan oleh Undang-Undang Dasar”.

c. "Memutus pembubaran partai politik"

d. "Memutus perselisihan tentang hasil pemilihan umum"

e. "Wajib memberikan putusan atas Pendapat Dewan Perwakilan Rakyat mengenai dugaan pelanggaran oleh Presiden dan/atau Wakil Presiden Menurut Undang-Undang Dasar".

Dalam hal kedudukan hukum (Legal Standing) Pemohon, bahwa berdasarkan Pasal 51 ayat (1) UU MK beserta Penjelasannya, yang dapat mengajukan permohonan pengujian Undang-Undang terhadap “UUD NRI 1945” adalah mereka yang menganggap hak dan/atau kewenangan konstitusionalnya yang diberikan oleh "UUD NRI 1945" dirugikan

\footnotetext{
${ }^{5}$ Cheng Joan Karmel Toryanto, Implementasi Putusan Mahkamah Konstitusi Nomor 69/PUU-XIII/2015

Tentang Perjanjian Kawin Terhadap Golongan Penduduk Yang Tunduk pada Kitab Undang-Undang Hukum Perdata.Skripsi.(Semarang: Universitas Diponegoro.2019).hlm46

${ }^{6}$ Faiz Rahman dan Dian Agung Wicaksono," Eksistensi dan Karakteristik Putusan Bersyarat Mahkamah Konstitusi”, Jurnal Konstitusi, Edisi No.2 Vol. 13, Fakultas Hukum Universitas gajah Mada, 2016,hlm 349-350
} 


\begin{tabular}{llrr}
\hline \hline Volume: & 3 & E-ISSN: & $2655-1942$ \\
Number: & 1 & Terbitan: & Juni 2020 \\
Page : & $121-141$ & & \\
\hline
\end{tabular}

oleh berlakunya suatu Undang-Undang, yaitu:

a. perorangan warga negara Indonesia (termasuk kelompok orang yang mempunyai kepentingan sama);

b. kesatuan masyarakat hukum adat sepanjang masih hidup dan sesuai dengan perkembangan masyarakat dan prinsip Negara Kesatuan Republik Indonesia yang diatur dalam Undang-Undang;

c. badan hukum publik atau privat; atau

d. lembaga negara;

Dengan demikian, Pemohon dalam pengujian Undang-Undang terhadap "UUD NRI 1945" harus menjelaskan terlebih dahulu:

a. kedudukannya sebagai Pemohon sebagaimana dimaksud dalam Pasal 51 ayat (1) UU MK;

b. ada tidaknya kerugian hak dan/atau kewenangan konstitusional yang diberikan oleh UUD 1945 yang diakibatkan oleh berlakunya Undang-Undang yang dimohonkan pengujian

Kerugian hak dan/atau kewajiban konstitusional yang diderita oleh seorang warga Negara haruslah memenuhi 5 (lima) syarat;

a. adanya hak dan/atau kewenangan konstitusional Pemohon yang diberikan oleh UUD 1945;

b. hak dan/atau kewenangan konstitusional tersebut oleh Pemohon dianggap dirugikan oleh berlakunya Undang-Undang yang dimohonkan pengujian;

c. kerugian konstitusional tersebut harus bersifat spesifik (khusus) dan aktual atau setidak-tidaknya potensial yang menurut penalaran yang wajar dapat dipastikan akan terjadi;

d. adanya hubungan sebab-akibat (causal verband) antara kerugian dimaksud dan berlakunya Undang-Undang yang dimohonkan pengujian;

e. adanya kemungkinan bahwa dengan dikabulkannya permohonan maka kerugian konstitusional seperti yang didalilkan tidak akan atau tidak lagi terjadi;

Dalam "Putusan MK Nomor 69/PUU-XII/2015" ini diajukan oleh Nyonya Ike Farida seorang Warga Negara Indonesia (WNI) yang menikah dengan seorang Warga Negara Jepang (WNA). Semasa dalam perkawinan tersebut, Nyonya Ike Farida ingin membeli asset 


\begin{tabular}{llrr}
\hline \hline Volume: & 3 & E-ISSN: & $2655-1942$ \\
Number: & 1 & Terbitan: & Juni 2020 \\
Page : & $121-141$ & & \\
\hline
\end{tabular}

berupa apartemen, tetapi karena pada saat menikah dahulu tidak membuat perjanjian kawin, maka pihak developer tidak dapat menjual unit apartemen tersebut karena adanya ketentuan yang berlaku dalam konteks hukum tanah nasioal yaitu ketentuan pada Undang-Undang Pokok Agraria (UUPA) yang menganut asas nasionalitas. Asas nasionalitas berarti bahwa hanya WNI saja yang dapat memiliki hak atas tanah Indonesia. Sesuai dengan ketentuan “Pasal 36 Ayat (1) dan Pasal 35 Ayat (1) UUP”, seorang perempuan WNI yang kawin dengan warga negara asing tidak dapat memiliki hak milik untuk membeli tanah dan atau bangunan tanpa adanya perjanjian kawin terlebih dahulu.

Oleh karena pihak developer memutuskan untuk tidak melakukan Perjanjian Pengikatan Jual Beli (PPJB) ataupun membuat Akta Jual Beli (AJB) dengan Pemohon Nyonya Ike Farida, karena dianggap akan melanggar ketentuan "Pasal 36 Ayat (1) dan Pasal 35 Ayat (1) UUP”. Dengan adanya hal ini, Pemohon Nyonya Ike Farida merasa dibedakan haknya sebagai warga Negara Indonesia, dan mengajukan Judicial Review mengenai permasalahan tersebut ke Mahkamah Konstitusi karena merasa telah dirugikan haknya ${ }^{7}$. Pasal-pasal yang dianggap telah merugikan haknya adalah sebagai berikut;

a. "Pasal 21 Ayat (1) UUPA yang berbunyi"

Hanya warganegara Indonesia dapat mempunyai hak milik",

b. Pasal 21 Ayat (3) yang berbunyi

"Orang asing yang sesudah berlakunya Undang-Undang ini memperoleh hak milik karena pewarisan tanpa wasiat atau percampuran harta karen aperkawinan, demikian pula warganegara Indonesia yang mempunyai hak milik dan setelah berlakunya Undang - Undang ini kehilangan kewarganegaraannya wajib melepaskan hak itu dalam jangka waktu satu tahun sejak diperolehnya hak tersebut atau hilangnya kewarganegaraan itu. Jika sesudah jangka waktu tersebut lampau hak milik tidak dilepaskan, maka hak tersebut hapus karena hokum dan tanahnya jatuh pada Negara, dengan ketentuan bahwa hak-hak pihak lain yang membebannya tetap berlangsung."

c. Pasal 36 Ayat (1) UUPA yang berbunyi:

"Yang dapat mempunyai hak guna bangunan ialah:

${ }^{7}$ Ery Agus Priyono, Herni Widanarti, and Dharu Triasih, 'Arti Penting Jawaban Atas Gugatan Sebagai Upaya Mempertahankan Hak - Hak Tergugat', Law, Development \& Justice Review, 2.1 (2019), hlm.6. 


\begin{tabular}{llrr}
\hline \hline Volume: & 3 & E-ISSN: & $2655-1942$ \\
Number: & 1 & Terbitan: & Juni 2020 \\
Page : & $121-141$ & & \\
\hline
\end{tabular}

(a) Warganegara Indonesia;

(b) Badan hokum yang didirikan menurut hukum Indonesia dan berkedudukan di Indonesia."

d. Pasal 29 Ayat (1) UUP yang berbunyi:

“ Pada waktu atau sebelum perkawinan dilangsungkan kedua belah pihak atas persetujuan bersama dapat mengajukan perjanjian tertulis yang disahkan oleh pegawai pencatat perkawinan, setelah mana isinya berlaku juga terhadap pihak ketiga tersangkut"

e. Pasal 29 Ayat (3) UUP yang berbunyi:

"Perjanjian tersebut dimulai berlaku sejak perkawinan dilangsungkan"

f. Pasal 29 Ayat (4) UUP yang berbunyi:

"Selama perkawinan dilangsung perjanjian tersebut tidak dapat diubah, kecuali bila dari kedua belah pihak ada persetujuan untuk mengubah dan perubahan tidak merugikan pihak ketiga",

g. Pasal 35 Ayat (1) UUP yang berbunyi

"Harta benda yang diperoleh selama perkawinan menjadi harta bersama”

Bersadarkan pasal tersebut, pemohon merasa terdiskriminasi dan dilanggar Hak Asasi Pemohon untuk mempunyai Hak Milik dan Hak Guna Bangunan sebagai Warga Negara Indonesia. Hak Konstitusional Pemohon untuk bertempat tinggal dan mendapatkan lingkungan hidup yang baik telah dirampas selamanya. Selain itu Pemohon juga merasa bahwa selama menjadi warga Negara Indonesia selalu menjunjung tinggi hukum, dan menjalankan kewajiban sebagaimana mestinya serta setia dan taat pada Negara Indonesia, akan tetapi dengan dengan diberlakukannya Pasal tersebut Pemohon merasa dibedakan haknya dengan warga Negara yang lain.

Berdasarkan hal tersebut, menurut Mahkamah Konstitusi kerugian Pemohon karena berlakunya "Pasal 21 ayat (1), ayat (3) dan Pasal 36 ayat (1) UU 5/1960; serta Pasal 29 ayat (1), ayat (3), ayat (4), dan Pasal 35 ayat (1) UU 1/1974" adalah spesifik, riil, dan nyata (actual), serta telah terjadi dan dirasakan oleh Pemohon. Hal tersebut juga memiliki hubungan sebab akibat dan hubungan kausal dengan Pemohon (causal verband). Sehingga tidak terbantahkan permohonan pengujian Undang-Undang Pemohon telah memenuhi seluruh 


\begin{tabular}{llrr}
\hline \hline Volume: & 3 & E-ISSN: & $2655-1942$ \\
Number: & 1 & Terbitan: & Juni 2020 \\
Page : & $121-141$ & &
\end{tabular}

syarat-syarat.

Berdasarkan pada "Pasal 51 ayat (1) UU MK" dan putusan Mahkamah mengenai kedudukan hukum (legal standing) serta dikaitkan dengan kerugian yang dialami oleh Pemohon, menurut Mahkamah:

a. Pemohon mempunyai hak konstitusional yang diberikan oleh UUD 1945, khususnya Pasal 28D ayat (1), Pasal 27 ayat (1), Pasal 28E ayat (1), serta Pasal 28H ayat (1) dan ayat (4), serta Pemohon menganggap hak konstitusional tersebut dirugikan oleh berlakunya Undang-Undang yang dimohonkan pengujian;

b. Kerugian konstitusional Pemohon setidak-tidaknya potensial yang menurut penalaran yang wajar dapat dipastikan akan terjadi;

c. Terdapat hubungan sebab-akibat (causal verband) antara kerugian dimaksud dan berlakunya Undang-Undang yang dimohonkan pengujian, serta ada kemungkinan bahwa dengan dikabulkannya permohonan maka kerugian konstitusional seperti yang didalilkan tidak akan atau tidak lagi terjadi;

d. Dengan demikian bahwa oleh karena Mahkamah berwenang mengadili permohonan a quo dan Pemohon memiliki kedudukan hukum (legal standing) untuk mengajukan permohonan a quo, maka Mahkamah akan mempertimbangkan pokok permohonan.

Dalam hal pokok permohonan Mahkamah Konstitusi melakukan pengujian terhadap pasal-pasal yang dianggap merugikan dan mendiskriminasi pemohon yang tercantum dalam UUPA yaitu pada "Pasal 21 Ayat (1) dan (3) serta Pasal 36 Ayat (1)" maupun dalam UUP yang tercantum pada "Pasal 29 Ayat (1), (3), dan (4) serta Pasal 35 Ayat (1)".

\section{Pengujian Terhadap Pasal 21 Ayat (1) dan (3) serta Pasal 36 Ayat (1) UUPA}

Salah satu prinsip atau asas UU 5/1960 adalah asas nasionalitas (kebangsaan), asas ini berintikan bahwa hanya bangsa Indonesia saja yang dapat mempunyai hubungan sepenuhnya dengan bumi (tanah) air, ruang angkasa, dan kekayaan yang terkandung di dalamnya. Pemberlakuan asas nasionalitas adalah sebagai jaminan hak-hak warga negara terhadap halhal yang berkaitan dengan sistem pertanahan dan sebagai pembatas hak-hak warga negara 


\begin{tabular}{llrr}
\hline \hline Volume: & 3 & E-ISSN: & $2655-1942$ \\
Number: & 1 & Terbitan: & Juni 2020 \\
Page : & $121-141$ & & \\
\hline
\end{tabular}

asing terhadap tanah di Indonesia. UU 5/1960 mengatur bahwa seluruh wilayah Indonesia adalah kesatuan tanah air dari seluruh rakyat Indonesia yang bersatu sebagai bangsa Indonesia. Oleh sebab itulah dalam UU 5/1960 disebutkan asas kebangsaan. Ketentuan dalam norma UU 5/1960 yang bertolak pada asas nasionalitas termuat dalam "Pasal 1, Pasal 2, Pasal 9, Pasal 20 ayat (1), Pasal 21 ayat (2), Pasal 30 ayat (1), Pasal 31 ayat (1) dan Pasal 46 ayat (1)."

“"Pasal 9 UU 5/1960” menyatakan:

(1) Hanya warga negara Indonesia dapat mempunyai hubungan yang sepenuhnya dengan bumi, air dan ruang angkasa, dalam batas-batas ketentuan Pasal 1 dan 2.

(2) Tiap-tiap warga negara Indonesia, baik laki-laki maupun wanita mempunyai kesempatan yang sama untuk memperoleh sesuatu hak atas tanah serta untuk mendapat manfaat dari hasilnya, baik bagi diri sendiri maupun keluarganya.

Norma "Pasal 9 UU 5/1960" merupakan penegasan bahwa hanya WNI yang berhak memiliki tanah di Indonesia, sedangkan warga negara asing (WNA) atau badan usaha asing hanya dapat mempunyai hak atas tanah yang terbatas saja seperti hak pakai. Orang Asing termasuk perwakilan perusahaan asing hanya dapat mempunyai hak yang terbatas atas tanah, selama kepentingan WNI tidak terganggu dan juga perusahaan asing itu dibutuhkan untuk kepentingan negara Indonesia sebagai komponen pendukung dalam pembangunan ekonomi Indonesia. Dapat diketahui bahwa hanya warga negara Indonesia saja yang boleh memiliki hak milik atas tanah. "Pasal 21 ayat (1) UU 5/1960" menentukan hanya warga negara Indonesia yang dapat mempunyai hak milik. Hak milik merupakan hak turun temurun, terkuat dan terpenuh yang dapat dipunyai orang atas tanah tanpa mengabaikan fungsi sosial dari tanah. Ketentuan mengenai asas nasionalitas pada "UU 5/1960 juga ditemukan dalam Pasal 36 ayat (1) UU 5/1960" yang mengatur bahwa hak guna bangunan dimiliki oleh WNI dan badan hukum yang didirikan menurut hukum Indonesia dan berkedudukan di Indonesia. “Norma Pasal 36 ayat (1) UU 5/1960 juga dimohonkan pengujian konstitusionalitasnya oleh Pemohon, sehingga dasar pemikiran tentang pemberlakuan asas nasionalitas sebagaimana diuraikan di atas juga menjiwai Pasal 36 ayat (1) UU 5/1960”.

Terhadap adanya permohonan Pemohon mengenai frasa "warga negara Indonesia" dalam "Pasal 21 ayat (1) dan Pasal 36 ayat (1) UU 5/1960" dimaknai warga negara Indonesia 


\begin{tabular}{llrr}
\hline \hline Volume: & 3 & E-ISSN: & $2655-1942$ \\
Number: & 1 & Terbitan: & Juni 2020 \\
Page : & $121-141$ & & \\
\hline
\end{tabular}

tanpa terkecuali dalam segala status perkawinan, baik warga negara Indonesia yang tidak kawin, warga negara Indonesia yang kawin dengan sesama warga negara Indonesia dan warga negara Indonesia yang kawin dengan warga negara asing, menurut Mahkamah, justru akan mempersempit pengrertian warga negara Indonesia sebagaimana diatur dalam Pasal 2 dan "Pasal 4 Undang-Undang Nomor 12 Tahun 2006 tentang Kewarganegaraan Republik Indonesia (selanjutnya disebut UU 12/2006)".

\section{Pengujian Pasal 29 Ayat (1), (2), dan (4) serta Pasal 35 Ayat (1) UUP}

Perkawinan sebagaimana dimaksud dalam "Pasal 1 UU 1/1974" adalah ikatan lahir batin antara seorang pria dan seorang wanita sebagai suami istri dengan tujuan membentuk keluarga atau rumah tangga yang bahagia dan kekal berdasarkan Ketuhanan Yang Maha Esa. Dalam sebuah perkawinan hak dan kedudukan seorang istri adalah seimbang dengan hak dan kedudukan seorang suami.

Bahwa di dalam kehidupan suatu keluarga atau rumah tangga, selain masalah hak dan kewajiban sebagai suami dan istri, masalah harta benda juga merupakan salah satu faktor yang dapat menyebabkan timbulnya berbagai perselisihan atau ketegangan dalam suatu perkawinan, bahkan dapat menghilangkan kerukunan antara suami dan istri dalam kehidupan suatu keluarga. Untuk menghindari hal tersebut maka dibuatlah perjanjian perkawinan antara calon suami dan istri, sebelum mereka melangsungkan perkawinan.

Perjanjian perkawinan dibuat berdasarkan kesepakatan kedua belah pihak secara tertulis yang disahkan oleh Petugas Pencatat Perkawinan, sebelum perkawinan itu berlangsung atau pada saat perkawinan berlangsung dan perjanjian perkawinan tersebut mulai berlaku sejak perkawinan itu dilangsungkan. Perjanjian kawin berlaku sebagai Undang-Undang bagi mereka yang membuatnya, juga berlaku bagi pihak ketiga yang memiliki kepentingan terhadapnya.

Alasan yang umumnya dijadikan landasan dibuatnya perjanjian setelah perkawinan adalah adanya kealpaan dan ketidaktahuan bahwa dalam UU 1/1974 ada ketentuan yang mengatur mengenai Perjanjian Perkawinan sebelum pernikahan dilangsungkan. Menurut Pasal 29 UU 1/1974, Perjanjian Perkawinan dapat dibuat pada waktu atau sebelum perkawinan dilangsungkan. Alasan lainnya adalah adanya risiko yang mungkin timbul dari 


\begin{tabular}{llrr}
\hline \hline Volume: & 3 & E-ISSN: & $2655-1942$ \\
Number: & 1 & Terbitan: & Juni 2020 \\
Page : & $121-141$ & & \\
\hline
\end{tabular}

harta bersama dalam perkawinan karena pekerjaan suami dan isteri memiliki konsekuensi dan tanggung jawab pada harta pribadi, sehingga masing-masing harta yang diperoleh dapat tetap menjadi milik pribadi.

Bahwa tujuan dibuatnya Perjanjian Perkawinan adalah:

a. Memisahkan harta kekayaan antara pihak suami dengan pihak istri sehingga harta kekayaan mereka tidak bercampur. Oleh karena itu, jika suatu saat mereka bercerai, harta dari masing-masing pihak terlindungi, tidak ada perebutan harta kekayaan bersama atau gono-gini.

b. Atas hutang masing-masing pihak pun yang mereka buat dalam perkawinan mereka, masing-masing akan bertanggung jawab sendiri-sendiri.

c. Jika salah satu pihak ingin menjual harta kekayaan mereka tidak perlu meminta ijin dari pasangannya (suami/istri).

d. Begitu juga dengan fasilitas kredit yang mereka ajukan, tidak lagi harus meminta ijin terlebih dahulu dari pasangan hidupnya (suami/istri) dalam hal menjaminkan aset yang terdaftar atas nama salah satu dari mereka.

Ketentuan yang ada saat ini hanya mengatur perjanjian perkawinan yang dibuat sebelum atau pada saat perkawinan dilangsungkan, padahal dalam kenyataannya ada fenomena suami istri yang karena alasan tertentu baru merasakan adanya kebutuhan untuk membuat Perjanjian Perkawinan selama dalam ikatan perkawinan. Selama ini sesuai dengan Pasal 29 UU 1/1974, perjanjian yang demikian itu harus diadakan sebelum perkawinan dilangsungkan dan harus diletakkan dalam suatu akta notaris. Perjanjian perkawinan ini mulai berlaku antara suami dan isteri sejak perkawinan dilangsungkan. Isi yang diatur di dalam perjanjian perkawinan tergantung pada kesepakatan pihak-pihak calon suami dan isteri, asal tidak bertentangan dengan Undang-Undang, agama, dan kepatutan atau kesusilaan. Adapun terhadap bentuk dan isi perjanjian perkawinan, kepada kedua belah pihak diberikan kebebasan atau kemerdekaan seluas-luasnya (sesuai dengan asas hukum "kebebasan berkontrak").

Frasa "pada waktu atau sebelum perkawinan dilangsungkan" dalam Pasal 29 ayat (1), frasa “...sejak perkawinan dilangsungkan" dalam Pasal 29 ayat (3), dan frasa "selama perkawinan berlangsung" dalam Pasal 29 ayat (4) UU 1/1974 membatasi kebebasan 2 (dua) 


\begin{tabular}{llrr}
\hline \hline Volume: & 3 & E-ISSN: & $2655-1942$ \\
Number: & 1 & Terbitan: & Juni 2020 \\
Page : & $121-141$ & & \\
\hline
\end{tabular}

orang individu untuk melakukan atau kapan akan melakukan "perjanjian", sehingga bertentangan dengan Pasal 28E ayat (2) UUD 1945 sebagaimana didalilkan Pemohon. Dengan demikian, frasa "pada waktu atau sebelum perkawinan dilangsungkan" dalam Pasal 29 ayat (1) dan frasa "selama perkawinan berlangsung" dalam Pasal 29 ayat (4) UU 1/1974 adalah bertentangan dengan UUD 1945 secara bersyarat sepanjang tidak dimaknai termasuk pula selama dalam ikatan perkawinan.

Sementara itu, terhadap dalil Pemohon mengenai inkonstitusionalitas Pasal 35 ayat (1) UU 1/1974, Mahkamah mempertimbangkan bahwa dengan dinyatakannya Pasal 29 ayat (1) UU 1/1974 bertentangan dengan UUD 1945 secara bersyarat maka ketentuan Pasal 35 ayat (1) UU 1/1974 harus dipahami dalam kaitannya dengan Pasal 29 ayat (1) UU 1/1974 dimaksud. Dengan kata lain, tidak terdapat persoalan inkonstitusionalitas terhadap Pasal 35 ayat (1) UU 1/1974. Hanya saja bagi pihak-pihak yang membuat perjanjian perkawinan, terhadap harta bersama sebagaimana dimaksud dalam Pasal 35 ayat (1) UU 1/1974 tersebut berlaku ketentuan tentang perjanjian perkawinan sesuai dengan yang dimaksud dalam Pasal 29 ayat (1) UU 1/1974 sebagaimana disebutkan dalam amar putusan ini. Dengan demikian, dalil Pemohon sepanjang mengenai inkonstitusionalitas Pasal 35 ayat (1) UU 1/1974 tidak beralasan menurut hukum.

Menimbang berdasarkan seluruh pertimbangan tersebut di atas, menurut Mahkamah, permohonan Pemohon sepanjang menyangkut "Pasal 29 ayat (1), ayat (3), dan ayat (4) UU 1/1974 beralasan menurut hukum untuk sebagian, sedangkan menyangkut Pasal 35 ayat (1) UU 1/1974 tidak beralasan menurut hukum".

\section{Implementasi Putusan Mahkamah Konstitusi RI No. 69/PUU-XIII/2015 terhadap hukum perkawinan di Indonesia}

Berdasarkan pertimbangan hakim yang telah dipaparkan pada pokok bahasan sebelumnya, Pada tanggal 27 Oktober 2016 Mahkamah Konstitusi mengeluarkan Putusan Nomer 69/PUU-XIII/2015 dengan amar pada pokoknya sebagai berikut:

a. "Pasal 29 Ayat (1) UU Perkawinan bertentangan dengan UUD NRI 1945" dan tidak mempunyai kekuatan hukum yang mengikat sepanjang tidak dimaknai " Pada waktu, sebelum dilangsungkan atau selama dalam ikatan perkawinan kedua belah pihak atas persetujuan bersama dapat mengajukan perjanjian tertulis yang disahkan oleh pegawai 


\begin{tabular}{llrr}
\hline \hline Volume: & 3 & E-ISSN: & $2655-1942$ \\
Number: & 1 & Terbitan: & Juni 2020 \\
Page : & $121-141$ & & \\
\hline
\end{tabular}

pencatat perkawinan atau notaris, setelah mana isinya juga berlaku juga terhadap pihak ketiga sepanjang pihak ketiga tersangkut"

b. "Pasal 29 ayat (3) UU Perkawinan bertentangan dengan UUD NRI 1945" dan tidak mempunyai kekuatan hukum yang mengikat sepanjang tidak dimaknai "Perjanjian tersebut mulai berlaku sejak perkawinan dilangsungkan, kecuali ditentukan lain dalam Perjanjian Perkawinan"

c. "Pasal 29 Ayat (1) UU Perkawinan bertentangan dengan UUD NRI 1945" dan tidak mempunyai kekuatan hukum yang mengikat sepanjang tidak dimaknai "Selama perkawinan berlangsung, perjanjian perkawinan dapat mengenai harkat perkawinan atau perjanian lainnya, tidak dapat diubah atau dicabut, kecuali bila dari kedua belah pihak ada persetujuan untuk mengubah atau mencabut, dan perubahan atau pencabutan itu tidak merugikan pihak ketiga"

Dengan dikeluarannya "Putusan Mahkamah Konstitusi Nomor 69/PUU-XIII/2015 "tersebut, maka harus dijalankan karena putusan Mahkamah Konstitusi bersifat final and binding dimana putusan tersebut berlaku tanpa adanya upaya hukum banding serta bersifat erga omnes yang berarti bahwa Putusan Mahkamah Konstitusi tersebut berlaku untuk seluruh warga Negara Indonesia, tidak hanya sebatas pada pemohon yang mengajukan saja.

Setelah keluarnya "Putusan Mahkamah Konstitusi Nomor 69/PUU-XIII/2015 "pada tanggal 27 Oktober 2016, dalam rangka pelaksanaan terhadap putusan tersebut dikeluarkan Surat Edaran Direktur Jenderal Kependudukan dan Pencatatan Sipil - Departemen Dalam Negeri RI No. 472.2/5857/DUKCAPIL bagi yang beragama selain Islam dan Surat Edaran Direktur Jenderal Bimbingan Masyarakat Islam - Kementerian Agama RI Nomor B.2674/DJ.III/KW.00/9/2017 bagi yang beragama Islam, yang pada pokoknya mengatur teknis pencatatan dan pelaporan Perjanjian Perkawinan yang dibuat sebelum, pada saat, dan selama ikatan perkawinan.

Dengan dikeluarkannya Surat Edaran baik dalam lingkup Dinas Kependudukan dan Catatan Sipil maupun dalam lingkup Kementerian Agama RI setelah keluarnya "Putusan Mahkamah Kosntitusi Nomor 69/PUU-XIII/2015" maka pelaksanaan amar putusan yang ada dapat dilaksanakan bagi pihak-pihak terkait yaitu, pihak yang melakukan perjanjian perkawinan, Notaris, Hakim, dan pihak ketiga yang terlibat dalam perjanjian kawin. 


\begin{tabular}{llrr}
\hline \hline Volume: & 3 & E-ISSN: & $2655-1942$ \\
Number: & 1 & Terbitan: & Juni 2020 \\
Page : & $121-141$ & & \\
\hline
\end{tabular}

Pembuatan perjanjian kawin seperti yang dipaparkan dalam surat edaran dilakukan dengan menggunakan akta yang dibuat dihadapan notaris atau akta otentik, meskipun dalam pasal 29 Undang-Undang Perkawinan yang telah diubah berdasarkan "Putusan Mahkamah Konstitusi Nomor 69/PUU-XIII/2015" tersebut tidak menyebutkan keharusan harus dibuat di hadapan notaris.

Surat edaran yang dibuat seharusnya tidak bertentangan dengan peraturan perundangundangan yang ada di atasnya, dalam hal ini adalah Undang-Undang Perkawinan dimana dalam surat edaran diharuskan membuat akta otentik terhadap perjanjian kawin, sedangkan dalam Undang-Undang Perkawinan tidak mengharuskan.

Berdasarkan hasil penelitian yang telah dilakukan terdapat beberapa pendapat mengenai perjanjian perkawinan hal ini yaitu pendapat Ibu Ria Desvia selaku Notaris, hakim Pengadilan Negeri Jakarta Barat Bapak Agus Setiawan,SH.,M.Hum. dan pihak yang mengajukan permohonan pengujian Undang-Undang Perkawinan dan Undang-Undang Pokok Agraria terhadap Undang-Undang Dasar 1945 yaitu Ibu Dr.Ike Farida, S.H.,LL.M.,.

Menurut Ria Desvia selaku Notaris yang berada di daerah Bekasi mengatakan bahwa beliau belum berani membuat akta perjanjian kawin karena belum adanya peraturan yang jelas dan tegas mengenai aturan pelaksanaannya untuk para notaris. Hal ini berdasarkan prinsip kehati-hatian yang lebih dari para notaris sebagai upaya untuk melindungi diri dari hal-hal yang mungkin akan terjadinya di kemudian hari atas itikad buruk dari para pihak.

Sebelum adanya Putusan Mahkamah Kosntitusional, pembuatan Perjanjian Perkawinan setelah perkawinan sudah ditaur dalam Pasal 186 KUH Perdata. Perjanjian yang dibuat dalam ikatan perkawinan harus ada alasan tertentu yang melatar belakanginya. Namun sebelum membuat perjanjian perkawinan haruslah didahului dengan mengajukan permohonan ke Pengadilan yang berwenang agar mendapatkan suatu penetapan dari hakim. Selanjutnya setelah mendapatkan penetaapan dari pengadilan, para pihak baik suami maupun isteri barulah dapat membuat perjanjianperkawinan setelah kawin di hadapan notaris.

Setelah mendapatkan penetapan dari pengadilan, maka akan menempatkan notaris pada posisi yang lebih aman karena akta perjanjian kawin yang dibuat adalah berdasarkan penetapan pengadilan. Dengan adanya penetapan pengadilan, dapat meminimalisir kemunginan dikemudian hari tidak terdapat gugatan yang dilakukan oleh pihak ketiga di 


\begin{tabular}{llrr}
\hline \hline Volume: & 3 & E-ISSN: & $2655-1942$ \\
Number: & 1 & Terbitan: & Juni 2020 \\
Page : & $121-141$ & & \\
\hline
\end{tabular}

pengadilan karena hakim telah memeriksa terlebih dahulu terhadap pemohon baik suami maupun isteri untuk membuat perjanjian kawin. ${ }^{8}$

Pendapat lain justru dikemukakan oleh Hakim Pengadilan Negeri Jakarta barat, Bapak Agus Setiawan,SH.,M.Hum. yang menyatakan bahwa setuju dengan adanya "Putusan Mahkamah Kosntitusi Nomor 69/PUU-XIII/2015”. Pada dasarnya semua perjanjian adalah kesepakatan semua pihak, termasuk perjanjian perkawinan. sehingga sela para pihak setuju dan sepakat, perjanjian kawin setelah perkawinan dapat di buat, dan jika kedepannya ada pihak yang merasa dirugikan karena perjanjian kawin tersebut dapat menggugat ke pengadilan. Dalam hal pemuatan perjanjian perkawinan dihadapan notaris apabila terdapat masalah dikemudian hari bertugas untuk bertanggung jawab atas awalan dan akhir perjanjian kawin tersebut bahwa benar pada hari dan tanggal tersebut, para pihakyang bersangkutan memang menghadap notaris dan menandatangani akta perjanjian tersebut, namun isi dari perjanjian tersebut adalah seluruhnya menjadi tanggung jawab para pihak yang membuat perjanjian perkawinan tersebut.

Dalam hal berkaitan dengan kepentingan pihak ketiga terhadap perjanjian perkawinan yang dibuat setelah perkawinan maka menimbulkan keresahan terhadap pihak ketiga yang terlibat, beliau berpendapat bahwa setelah perjanjian perkawinan telah dibuat dan mengacu pada Putusan Mahkamah Konstitusional, maka mengajukan permohonan penetapan ke pengadilan agar memerintahkan kepada Kantor Catatan Sipil dan Kantor Urusan Agama untuk mendaftarkannya atau mencatatkannya, sehingga dengan demikian akibat hukum perjanjian perkawinan tersebut dapat memberikan kepastian hukum bagi pihak ketiga. ${ }^{9}$

Hal yang sama disampaikan oleh pihak yang mengajukan permohonan pengajuan judicial review Undang-Undang Perkawinan dan Undang-Undang Pokok Agraria terhadap UndangUndang Dasar 1945 yaitu Ibu Dr.Ike Farida, S.H.,LL.M., bahwa dalam pelaksanaan perjanjian perkawinan yang dilakukan setelah perkawinan haruslah dicatat dan didafatarkan ke pejabat yang berwenang dimana dalam hal ini adalah Kantor Catatan Sipil bagi yang memeluk agama selain Islam dan kantor Urusan Agama bagi yang memeluk agama Islam. Dalam hal perjanjian perkawinan oleh suami dan istri wajib dibuat di hadapan notaris karena

\footnotetext{
${ }^{8}$ Wawancara dengan Ria Desviana, Notaris di Bekasi, tanggal 17 Juli 2019

${ }^{9}$ Wawancara dengan Agus Setiawan,SH.,M.Hum., Hakim Pengadilan Negeri Jakarta Barat, tanggal 16 Juli 2019
} 


\begin{tabular}{llrr}
\hline \hline Volume: & 3 & E-ISSN: & $2655-1942$ \\
Number: & 1 & Terbitan: & Juni 2020 \\
Page : & $121-141$ & & \\
\hline
\end{tabular}

dengan dibuat dihadapan notaris akan membuat perjanjian perkawinan tersebut menjadi bukti otentik yang berkekuatan hukum yang kuat apabila terdapat hal-hal yang tidak diinginkan.

Setelah dibuat di hadapan notaris yang ditunjuk, maka perjanjian perkawinan tersebut dicatatkan ke pejabat pencatat baik di Kantor Catatan Sipil Maupun Kantor Urusan Agama. Pencatatan dilakukan guna memberikan kepastian hukum bagi para pihak, termasuk pihak ketiga agar tidak mengalami kerugian setelah dilakukannya perjanjian perkawinan setelah melangsungkan perkawinan. setelah perjanjian dicatatkan maka dapat dijadikan lampiran bukti bagi WNI yang menikah dengan WNA dan akan membeli tanah/bangunan dengan status HGB dan HM agar dapat dilakukan jual beli terhadap tanah atau bangunan tersebut karena status kepemilikan tanah/bangunan tersebut bukan merupakan harta bersama yang dimiliki oleh pasangan WNA dan WNI, melainkan hanya dimiliki oleh WNI saja sehingga asas nasionalitas tersebut masih melekat dan WNI tetap mendaptakan hak untuk memiliki tanah / bangunan tersebut. ${ }^{10}$

Permasalahan perkawinan campuran sangat kompleks, karena nyatanya bahwa WNI perkawinan campuran banyak yang menikah secara siri (agama). Hal ini disebabkan salah satunya oleh Undang-Undang Nomor 62 ahun 1958 Tentang Kewarganegaraan (aturan lama) yang mengatur ketentuan bahwa perempuan WNI yang menikah dengan WNA maka otomatis kehilangan kewarganegaraannya. Oleh karena itu, untuk menghindari kehilangan kewarganegaraan Indonesianya, banyak WNI perkawinan campuran yang tidak mendaftarkan perkawinan pada kantor catatan sipil atau KUA.

Dalam hal legalitas perjanjian perkawinan terhadap perkawinan campuran yang dilakukan secara siri, perlu diketahui bahwa perjanjian perkawinan salah satu tujuannya adalah melakukan penyimpangan terhadap persatuan harta kekayaan yang diatur padal pasal 29 ayat (1) Undang-Undang Perkawinan. maka pegawai pencatat perkawinan dan notaris hanya menerima perkawinan yang telah tercatat. Ketentuan tersebut merupakan ketentuan yang segaris dengan ketentuan hukum nasional yang menyatakan bahwa tiap-tiap perkawinan dicatat menurut undang-undang yang berlaku. ${ }^{11}$

\footnotetext{
${ }^{10}$ Wawancara dengan Ibu Dr.Ike Farida, S.H.,LL.M., pihak pemohon pengajuan judicial review, tanggal 15 Juli 2019

${ }^{11}$ Arie S. Hutagalung dan Ike Farida, "Hukum Antar Tata Hukum (Kepemilikan tanah Bagi Pasangan Perkawinan Campuran Pasca Putusan Mahkamah Konstitusi Nomor 69/PUU-XIII/2015)”, (Depok : Badan Penerbit Fakultas Hukum Universtas Indonesia, 2018), hlm 89-92.
} 


\begin{tabular}{llrr}
\hline \hline Volume: & 3 & E-ISSN: & $2655-1942$ \\
Number: & 1 & Terbitan: & Juni 2020 \\
Page : & $121-141$ & & \\
\hline
\end{tabular}

\section{Kesimpulan}

Berdasarkan uraian yang telah dipaparkan dalam pembahasan di atas, maka dapat ditarik suatu kesimpulan yaitu Pertimbangan hakim dalam mengeluarkan "Putusan Mahkamah Nomor 69/PUU-XIII/2015" yang berkaitan dengan perjanjian perkawinan adalah bahwa segala sesuatu yang terjadi di dalam keluarga dapat dimusyawarahkan dan diputuskan bersama oleh suami isteri, bahkam dengan persetujuan bersama dapat membuat perjanjian tertulis elama tidak melanggar hukum yang berlaku, agama, kesusilaan, dan syarat sah perjanjian. Kemudian sering kali adanya kealpaan dan ketidaktauan mengenai ketentuan perjanjian perkawinan srta adanya risiko yang timbul terhadap Harta Bersama milik suami dan Istri. Menurut majelis hakim, tujuan dibuatnya perjanjian kawin adalah;

a) Memisahkan harta kekayaan antara pihak suami dengan pihak istri sehingga harta kekayaan mereka tidak bercampur. Oleh karena itu, jika suatu saat mereka bercerai, harta dari masing-masing pihak terlindungi, tidak ada perebutan harta kekayaan bersama atau gono-gini.

b) Atas hutang masing-masing pihak pun yang mereka buat dalam perkawinan mereka, masing-masing akan bertanggung jawab sendiri-sendiri.

c) Jika salah satu pihak ingin menjual harta kekayaan mereka tidak perlu meminta ijin dari pasangannya (suami/istri).

d) Begitu juga dengan fasilitas kredit yang mereka ajukan, tidak lagi harus meminta ijin terlebih dahulu dari pasangan hidupnya (suami/istri) dalam hal menjaminkan aset yang terdaftar atas nama salah satu dari mereka.

Implementasi "putusan Mahakamah Konstitusi Nomor 69/PUU-XIII/2015” dilaksanakan dengan dikeluarkannya "Surat Edaran Direktur Jenderal Kependudukan dan Pencatatan Sipil - Departemen Dalam Negeri RI No. 472.2/5857/DUKCAPIL” bagi yang beragama selain Islam dan "Surat Edaran Direktur Jenderal Bimbingan Masyarakat Islam - Kementerian Agama RI Nomor B.2674/DJ.III/KW.00/9/2017” bagi yang beragama Islam, yang pada pokoknya mengatur teknis pencatatan dan pelaporan Perjanjian Perkawinan yang dibuat sebelum, pada saat, dan selama ikatan perkawinan. yang mana dalam hal ini pihak pihak yang terkait adalah Notaris, Kantor Catatan Sipil dan Kantor Urusan Agama. Pencatatan dilakukan untuk melindungi kepentingan para pihak baik suami, istri maupun pihak ketiga. Pencatatan 


\begin{tabular}{llrr}
\hline \hline Volume: & 3 & E-ISSN: & $2655-1942$ \\
Number: & 1 & Terbitan: & Juni 2020 \\
Page : & $121-141$ & & \\
\hline
\end{tabular}

perjanjian perkawinan hanya dapat dilakukan terhadap pasangan suami isteri yang melakukan perkawinan secara sah dan tercatat, sementara pada perkawinan siri perjanjian perkawinan tidak dapat dilakukan.

Sehingga bagi para pembuat Undang-Undang yang memiliki kewenangan dalam membuat suatu peraturan hendaknya harus ada konsistensi antara peraturan yang terdahulu dengan peraturan yang baru terutama mengenai perjanjian perkawinan. Hal ini karena terdapat perbedaan tata cara pembuatan perjanjian "Perkawinan dalam KUH. Perdata, UUP, maupun setelah keluarnya putusan Mahkamah Konstitusi Nomor 69/PUU-XIII/2015”. Bagi para pembuat peraturan perundang-undangan dan pemerintah semestinya membuat aturan pelaksana seperti peraturan pemerintah sebagai tindak lanjut dari keluarnya putusan tersebut sehingga lebih dapat diketahui oleh masyarakat luas. Bagi Notaris sebagai pejabat yang berwenang dalam pembuatan akta perjanjian perkawinan hendaknya berhati-hati untuk melindungi kepentingan semua pihak dan kepentingan pihak ketiga agar tidak dilanggar hakhaknya.

\section{DAFTAR PUSTAKA}

\section{Buku-Buku}

Abdulkadir Muhammad, 2004, Hukum dan Penelitian Hukum, Bandung: PT. Citra Aditya Bakti, halaman 53.

Aditya P.Manjorang dan Intan Aditya, The Law of Love, h.37-39

Aminuddin dan Zainal Asikin, 2006, Pengantar Metode Penelitian Hukum, Jakarta,: PT Raja Berger, Peter L., The Secred Canopy, terj. Hartono, Langit Suci: Agama Sebagai Realitas Sosial, LP3ES, Jakarta, 1991.Sulaiman Rasyid, Fiqih Islam (Bandung: Sinar Baru Algesinda, 1994) hlm. 374

Fauzi, Romzan. Agama dan Kearifan Lokal.

H. Abdurrahman, Kompilasi Hukum Islam di Indonesia, Edisi Pertama, (Jakarta: Akademika Pressindo, 2007).

Heru Irianto dan Burhan Bungin, "Pokok-Pokok Penting tentang Wawancara" dalam Burhan Bungin (editor), Metodologi Penelitian Kualitatif Aktualisasi Metodologis ke Arah Ragam Varian Kontemporer, 2001, Jakarta : Raja Grafindo Perkasa.

Lexy J. Moleong, Metodologi Penelitian Kualitatif, (Bandung: PT remaja Rosdakarya, 2005)

Marilang, Hukum Perikatan Perikatan yang lahir dari Perjanjian, (Makassar: Alauddin University Press, 2013

Muhadjirin Thohir, Peranan Teori-Teori Sosial untuk Memahami Hukum dalam Kehidupan Mulyadi, Hukum Perkawinan Indonesia, Badan Penerbit Universitas Diponegoro Semarang, 2016.

Mulyadi, 2016, Hukum Perkawinan Indonesia, Semarang: Badan Penerbit Universitas Diponegoro.R.Subekti, Hukum Perjanjian, (Jakarta: PT Intermasa Jakarta, 1987), . 


\begin{tabular}{llrr}
\hline \hline Volume: & 3 & E-ISSN: & $2655-1942$ \\
Number: & 1 & Terbitan: & Juni 2020 \\
Page : & $121-141$ & & \\
\hline
\end{tabular}

Ridwan, Nurma Ali. 2007. “Landasan Keilmuan Kearifan Lokal”. Jurnal Studi Islam dan Budaya Ibda' Vol.5/No.1/Januari-Juni 2007. Purwokerto: P3M STAIN Purwokerto.

R. Soetojo Prawirohamidjojo dan Asis Safioedin, (1985), Hukum Orang dan Keluarga, Bandung: Alumni.

Soemitro, Ronny Hanitijo. "Metodologi penelitian hukum dan jurimetri." Ghalia Indonesia, Jakarta 167 (1990).

Soerjono Soekanto,1986, Pengantar Penelitian Hukum, Jakarta, UI-Press.

Sri Soesilowati Mahdi, Surini Ahlan dan Ahmad Budi Cahyono, Hukum Perorangan dan Kekeluargaan Perdata Barat, (Jakarta: Gitama Jaya, 2005)

Stefen Law, dalam Otje Salman dan Anthon F. Susanto, Teori Hukum, Mengingat, Mengumpulkan, dan Membuka Kembali, Refika Aditama Bandung, 2013

Sulaiman Rasyid. Fiqih Islam. Bandung: Sinar Baru Algesinda. 1994.

Werner Menki, Perbandingan Hukum dalam Konteks Global: Sistem Eropa, Asia, dan Afrika, Penerjemah M. Khozin Nusa Media, Bandung, 2012

Yudi Latif, Negara Paripurna, Historisitas, dan Aktualitas Pancasila, Cetakan Kedua, 2011.

\section{Perundang-undangan :}

Norma dasar Pancasila, Undang-Undang Dasar 1945;

Undang-Undang No.1 Tahun 1974 Tentang Perkawinan;

Undang-Undang Nomor 23 Tahun 2006 tentang Catatan Sipil;

UU No. 36 Tahun 2009 tentang Kesehatan;

UU No. 12 Tahun 2011 tentang Pembentukan Perundang-undangan terkait perbedaan batas usia;

UU No. 35 Tahun 2014 tentang Perlindungan Anak;

Peraturan Pemerintah No.9 Tahun 1975 Tentang Peraturan Pelaksanaan;

Keputusan Presiden Nomor 12 Tahun 1983 Tentang Penataan dan Peningkatan Pembinaan Penyelenggaraan Catatan Sipil;

Putusan MK No. 46 Tahun 2010 ttg Anak Luar Kawin;

Putusan MK No.69/PUU-XIII/2015 perjanjian kawin;

Putusan MK No. 97/PUU-XIV/2016 tentang Penghayat Kepercayaan

Website :

Wikipedia.com

Jurnal :

Ahmad Royani, Perjanjian Kawin Yang Dibuat Setelah Perkawinan Terhadap Pihak Ketiga (Pasca Putusan Mahkmah Konstitusi Nomor 69/PUU-XIII/201

Arie S. Hutagalung dan Ike Farida, "Hukum Antar Tata Hukum (Kepemilikan tanah Bagi Pasangan Perkawinan Campuran Pasca Putusan Mahkamah Konstitusi Nomor 69/PUU- XIII/2015)”, (Depok : Badan Penerbit Fakultas Hukum Universtas n Indonesia, 2018).

Benuf, Kornelius, and Muhamad Azhar, 'Metodologi Penelitian Hukum Sebagai Instrumen Mengurai Permasalahan Hukum Kontemporer’, Gema Keadilan, 7.1 (2020), 20-33

Priyono, Ery Agus, Herni Widanarti, and Dharu Triasih, 'Arti Penting Jawaban Atas Gugatan

Sebagai Upaya Mempertahankan Hak - Hak Tergugat', Law, Development \& Justice 


\begin{tabular}{llrr}
\hline \hline Volume: & 3 & E-ISSN: & $2655-1942$ \\
Number: & 1 & Terbitan: & Juni 2020 \\
Page : & $121-141$ & & \\
\hline
\end{tabular}

Review, 2.1 (2019), 1-7

Cheng Joan Karmel Toryanto, Implementasi Putusan Mahkamah Konstitusi Nomor 69/PUU-XIII/2015 Tentang Perjanjian Kawin Terhadap Golongan Penduduk Yang Tunduk pada Kitab Undang-Undang

HukumPerdata.Skripsi.(Sem rang:UniversitasDiponegoro. 2019).

Faiz Rahman dan Dian Agung Wicaksono, "Eksistensi dan Karakteristik Putusan Bersyarat Mahkamah Konstitusi”, Jurnal Konstitusi, Edisi No.2 Vol. 13,

Fakultas Hukum Universitas gajah Mada, 2016.

Fhauzi Prasetyawan, Peran Notaris Terkait Pengesahan Perjanjian Perkawinan Pasca Putusan Mahkamah Konstitusi Nomor 69/PUU-XII/2015, diakses pada tanggal 20 Maret 2019

Priesty Yustika Putri, Prija Djatmika, Dhiana Puspitawati, Implikasi Yuridis Perjanjian Perkawinan yang Dibuat Selama Dalam Ikatan Perkawinan Terhadap Utang Bersama Pasca Putusan Mahkamah Konstitusi Nomor 69/PUU-XIII/2015, diakses pada tanggal 20 Maret 2019

Sukardi, Kajian Yuridis Perjanjian Perkawinan Menurut Kitab Undang-Undang Hukum Perdata, Undang-Undang Nomor 1 Tahun 1974 dan Kompilasi Hukum Islam, diakses pada tanggal 20 Maret 2019

\section{Wawancara :}

Wawancara dengan Agus Setiawan,SH.,M.Hum., j Hakim Pengadilan Negeri h Jakarta Barat, tanggal 16 Juli 2019

Wawancara dengan Ibu Dr.Ike Farida, S.H.,LL.M., pihak pemohon pengajuan judicial review, tanggal 15 Juli 2019

Wawancara dengan Ria Desviana, Notaris di Bekasi, tanggal 17 Juli 2019 